Воронич Михайло Михайлович, аспірант Поліського національного університету, 10008, м. Житомир, Бульвар старий, 7, тел.: (068) 717-55-88, e-mail: mikhail.voronych@gmail.com, https//orcid.org/0000-0003-4876-5064

\title{
ПЕРСПЕКТИВНІ НАПРЯМИ ДІДЖИТАЛІЗАЦЇ̈ АГРАРНОГО СЕКТОРУ ЕКОНОМІКИ УКРАЇНИ
}

Анотація. Забезпечення конкурентних переваг виробників сільськогосподарської продукції в сучасних умовах глобалізації, гострої конкурентної боротьби на внутрішньому та зовнішніх аграрних ринках, відкритого доступу до необхідної інформації, стрімкого темпу науково-технічного розвитку неможливе без імплементації сучасних інформаційних технологій у господарську діяльність та діджиталізації господарського процесу. Впровадження цифрових технологій дасть можливість максимізувати ефективність прийняття управлінських рішень спираючись на результати обробки великих масивів даних, суттєво скоротити витрати часу та фінансових ресурсів на всіх етапах господарського процесу, оптимізувати виробничі та управлінські бізнес-процеси із урахуванням значущих для кожного окремого сільськогосподарського підприємства критеріїв ефективності. Крім того, методи та алгоритми, що лежать в основі більшості інформаційних систем, є адаптованими до прогнозування показників діяльності сільськогосподарських виробників.

Метою даного дослідження $є$ обгрунтування та систематизація ключових напрямів діджиталізації аграрного сектору України. У статті систематизовано основні інструменти діджиталізації аграрного сектора залежно від рівнів їх дії (у межах мікро-, мезо- та макрорівнів). Виділено ресурси, які потрібно додатково залучати для активізації впровадження діджитал-технологій. До таких ресурсів віднесено трудові, капітальні та інформаційні ресурси. Обгрунтовано, що на мезорівні доцільно створювати геоінформаційні портали складної багаторівневої структури. У процес розробки таких порталів, їх обслуговування та адміністрування, підготовки персоналу необхідної кваліфікації слід активно залучати вищі навчальні заклади. Розроблено алгоритм сценарного прогнозування розвитку агарного сектору України, який доцільно покласти в основу інформаційної системи. Відповідні середньострокові прогнози рекомендується покласти в основу підтримки прийняття рішень, які стосуються аграрної політики країни. Побудовано базовий сценарій розвитку агарного сектора.

Ключові слова: діджиталізація, цифровізація, аграрний сектор, сільськогосподарське підприємствао, геоінформаційний портал. 
Voronych Mykhailo Mikhailovich, Graduate Student, Polissia National University, 10008, Zhytomyr, Bulvar Staryi, 7, tel .: (068) 717-55-88, e-mail: mikhail.voronych@gmail.com, https//orcid.org/0000-0003-4876-5064

\section{THE DIRECTIONS OF DIGITALIZATION OF THE AGRICULTURAL SECTOR OF UKRAINIAN}

Abstract. Ensuring competitive advantages of agricultural producers in the modern conditions of globalization, intense competition in the domestic and foreign agricultural markets, open access to the necessary information, the intensive scientific and technological development, is impossible without the implementation of modern information technologies in economic activities and without the digitalization of the economic process. The introduction of digital technologies will maximize the efficiency of decision-making processes based on the results of analyzing big data, significantly reduce the time and financial resources spent at all stages of the economic process, optimize production and management business processes, taking into account the efficiency parameters that are significant for the specific agricultural enterprise. In addition, the methods and algorithms underlying most information systems are adapted to project the development of agricultural producers.

The purpose of this study is to substantiate and systematize the key areas of digitalization of the agricultural sector in Ukraine. The author systematizes the main tools for the digitalization of the agricultural sector, depending on the levels of their action (within the micro-, meso- and macrolevels). Resources that need to be additionally attracted to activate the introduction of digital technologies have been identified. These resources include labor, capital and information. It has been substantiated that it is important to create geo-information portals of a complex multi-level structure at the mesolevel. Higher education institutions should be involved in the development of such portals, their maintenance and administration, and the training of personnel with the required qualifications. An algorithm for scenario projecting the development of the agricultural sector of Ukraine has been developed. The corresponding medium-term projections are recommended to use as the basis for agrarian policy-making decisions. A baseline scenario for the development of the agricultural sector has been developed.

Key words: digitalization, agricultural sector, agricultural enterprise, geographic information portal.

Постановка проблеми. Забезпечення розвитку аграрного сектора економіки України в умовах поглиблення глобалізаційних процесів передбачає побудову цілісної системи інструментів, важелів та стимулів, які уможливлять формування стійких конкурентних переваг вітчизняних суб'єктів агробізнесу на внутрішньому та зовнішньому аграрних ринках. Наведене можливе лише за умови забезпечення високого рівня продуктивності ресурсів, що використовуються у процесі сільськогосподарського виробництва. Наразі діджиталізація (цифровізація) є одним 
iз основних напрямів оптимізації діяльності сільськогосподарських підприємств, який передбачає вдосконалення їх управлінських процесів на основі результатів обробки великих масивів даних шляхом максимально широкого використання інформаційних систем i технологій у господарському процесі. Шляхом імплементації сучасних технологій автоматизації обробки даних та прийняття рішень, по-перше, можливо об’єднати всі елементи господарського процесу підприємства у єдину цілісну систему, яка функціонуватиме заради досягнення його глобальної мети - забезпечення конкурентоспроможності та бажаного рівня ефективності діяльності. По-друге, сучасні математичні методи та алгоритми, які $\epsilon$ складовою математичного забезпечення таких систем, дають можливість розробляти середньо- та довгострокові варіантні прогнози, що мають лежать в основі стратегії розвитку сільськогосподарського підприємства.

Аналіз останніх досліджень і публікацій. Питання діджиталізації аграрного сектора стає дедалі більш досліджуваним науковою спільнотою. Зокрема, сучасні діджитал-технології та їх потенціал для виробників сільськогосподарської продукції, особливості діджитал-трансформацій вивчають такі зарубіжні науковці, як Н. Трендов, І. Варас, М. Зенг [9]. Колектив акторів на чолі С. Фаунтасом обгрунтували технології та можливості цифрового сільського господарства [7]. В. Сулімін, В. Шведов та М. Львова систематизували сучасні діджитал-технології, які доцільно впроваджувати в агросфері [8]. У науковій праці [6] увагу приділено обгрунтуванню доцільності діджиталізації аграрного сектору у країнах, що розвиваються. Що стосується вітчизняних дослідників, то вагомий внесок у розвиток досліджуваної тематики зробили О. Гудзь [1], А.Гуренко та О.Гашутіна [2], Г. Жосан [3], М. Руденко [4, 5] та ін. Незважаючи на незаперечну значущість наукового доробку перелічених та інших науковців, слід зазначити, що багатоаспектність діджиталізації аграрного сектору, а також стрімкість трансформацій іiі елементів та складність формалізації результатів іiі імплементації зумовлюють актуальність подальші дослідження цифровізації виробників аграрної продукції.

Мета статті - обгрунтування та систематизація ключових напрямів діджиталізації аграрного сектору України.

Виклад основного матеріалу. Однією 3 базових характеристик системи інформаційного забезпечення розвитку аграрного сектора України $\epsilon$ взаємопідсилюючий характер їі інструментарію, коли ефект від використання кожного окремого інструмента має сприяти збільшенню ефектів від впровадження інших. Саме у такий спосіб буде досягнуто синергетичний ефект від імплементації системи в цілому, що сприятиме поступовому переходу аграрного сектора України у якісно новий стан.

Умовно елементи системи інформаційного забезпечення розвитку агарного сектора можна згрупувати за рівнями їх впровадження. Такі рівні включатимуть мікрорівень (інструменти, що впроваджуватимуться суб'єктами бізнесу), мезо- та макрорівні (інструменти, важелі та стимули, сформовані на регіональному, 
включаючи рівень ОТГ, та державному рівнях), світовий рівень. Суб'єкти господарювання на мікрорівні є безпосередньо суб'єктами досягнення стратегічних цілей держави та глобальних цілей сталого розвитку. Елементи системи забезпечення розвитку аграрного сектора на меза-, макро- та світовому рівнях мають виконувати дві функції, бенефіціарами яких будуть суб’єкти мірорівня. Першою функцією є створення умов, які сприятимуть розвитку господарюючих суб'єктів i посиленню їх конкурентоспроможності. Друга функція - це стимулювання та мотивування суб’єктів агробізнесу до досягнення глобальних цілей.

В умовах надшвидкого науково-технічного розвитку й інформатизації суспільства ключова увага зосереджується діджиталізації аграрного сектора, яку наразі розглядають як наступний етап розвитку сільського господарства [9], що напряму пов'язаний із впровадженням та використанням сучасних цифрових технологій. Розглядаючи питання діджиталізації аграрного сектора економіки країни, першочергово слід досліджувати проблематику діджиталізації сільського господарства та процесів комунікації сільськогосподарських виробників із іншими сфера АПК.

Процес діджиталізації сільського господарства $є$ цілеспрямованим і тому потребує обгрунтування системи цілей, що охоплюють всі сфери господарювання від ресурсного забезпечення до переробки та реалізації продукції. Для кожної із сфер характерні свої інструменти діджиталізації, які у загальному можна згрупувати у такі групи як засоби технічного забезпечення, програмні засоби, інформаційні та комунікаційні технології. Особливістю зазначених груп є те, що вони перебувають у тісному взаємозв'язку і зазвичай є неефективними у разі використання однієї із них без застосування інших. Як результат, впровадження сукупності інструментів діджиталізації мають створювати певну системи, якій будуть характерні наступні властивості:

1) цілеспрямованість - наявність конкретних кількісно вимірюваних цілей із часовими строками реалізації, які інтегруються у систему цілей забезпечення сталого розвитку сільського господарства. До основних цілей сталого розвитку, які мають досягатись у процесі діджиталізації аграрного сектору економіки країни належить низка глобальних цілей, а саме: подолання голоду, забезпечення міцного здоров'я, надання якісної освіти, забезпечення доступу до чистої води, використання відновлювальної енергії, боротьба зі зміною клімату, збереження екосистем;

2) наявність синергетичного ефекту, коли цифрова трансформація господарського процесу призведе до якісного переходу сільськогосподарського підприємства на новий рівень розвитку. Наприклад, відбудеться якісна зміна якісних характеристик продукції, буде сформовано нові конкурентні переваги;

3) складна структура та тісна взаємодія інструментів діджиталізації між собою;

4) організація процесу діджиталізації 3 урахуванням тісних взаємозв'язків сільськогосподарського підприємства із зовнішнім середовищем (контрагентами, споживачами, іншими учасниками аграрних ринків, органами влади, науковими організаціями, освітніми установами тощо). 
Для досягнення загаданих вище цілей, процес діджиталізації має узгоджуватись із зазначеною вище ієрархією системи забезпечення розвитку аграрного сектора України (передусім, мікро-, мезо- та макрорівні). Оскільки на кожному із перелічених рівнів використовуються різні механізми забезпечення розвитку аграрного сектора, інструменти діджиталізації на них також різнитимуться. На мікрорівні основну увагу пропонується зосередити на цифровізації господарських процесів виробників сільськогосподарської продукції, як забезпечуючої ланки аграрного сектора країни. У розрізі сільськогосподарських виробників ключову роль відіграють інструменти діджиталізації двох сфер господарської діяльності виробництва та управління. В основі діджиталізації виробничих процесів у сільському господарстві лежить максимальна автоматизація та роботизація виробничих бізнес-процесів у рослинництві та тваринництві 3 метою централізованого управління обладнанням і технікою, а також організації збору та обробки даних щодо вхідних та вихідних параметрів виконання технологічних операції. Основними драйверами діджиталізації виробничих процесів є необхідність оптимізації використання ресурсів і високий рівень погодних ризиків через зміни клімату.

Додатково слід виділити важливість оптимізації використання земельних ресурсів. Забезпечення населення світу продовольством $\epsilon$ нагальним питанням, у т. ч. в контексті другої глобальної цілі сталого розвитку - подолання голоду. Водночас, високий рівень розораності сільськогосподарських угідь в Україні значно обмежує потенціал вітчизняного аграрного сектора щодо нарощення обсягів виробництва сільськогосподарської продукції за рахунок збільшення площі ріллі. У таких умовах вкрай важливою $\epsilon$ інтенсифікація виробництва, що передбачає збільшення обсягів виготовлення продукції не за рахунок розширення ресурсної бази (тобто залучених у виробничий процес додаткових земельних ресурсів), а шляхом підвищення рівня урожайності.

Основні інструменти діджиталізації виробничих процесів у сільському господарстві наведено у табл. 1. Серед найбільш напрямків перспективних слід виділити системи із використанням технологій інтернету речей (IoT), що передбачають інтеграцію технічних та технологічних рішень діджиталізації та їх взаємодію без втручання людини.

Таблиия 3.1

Основні інструменти діджиталізації виробничих процесів у сільському господарстві

\begin{tabular}{|l|l|l|}
\hline $\begin{array}{c}\text { Інструмент } \\
\text { діджиталізації }\end{array}$ & \multicolumn{1}{|c|}{ Виконувані функції } & \multicolumn{1}{|c|}{ Ключові особливості } \\
\hline \multicolumn{2}{|c|}{ Технічні рімення } \\
\hline Сенсори & $\begin{array}{l}\text { Моніторинг параметрів грунту (поживні речовини, } \\
\text { температура, вологість), рослин (температура, } \\
\text { щоденний ріст, індекси вегетації), погодних умов, } \\
\text { параметрів повітря, випромінювання }\end{array}$ & $\begin{array}{l}\text { Призначені для } \\
\text { оптимізації ресурсів }\end{array}$ \\
\hline
\end{tabular}




\begin{tabular}{|c|c|c|}
\hline & $\begin{array}{l}\text { (ультрафіолетового, радіаційного випромінювання, } \\
\text { випромінювання для фотосинтезу), популяції } \\
\text { шкідників, стану техніки і будівель тваринницьких } \\
\text { ферм }\end{array}$ & \\
\hline Роботизація & $\begin{array}{l}\text { Виконання технологічних операцій (обробіток } \\
\text { грунту, посів, внесення добрив, З3Р, прополка, } \\
\text { збирання, відбір проб грунту) без втручання людини } \\
\text { (у т. ч. із використанням сенсорів) }\end{array}$ & $\begin{array}{l}\text { Вивільнення трудових } \\
\text { ресурсів } \\
\text { Можуть працювати на } \\
\text { альтернативних } \\
\text { джерелах енергії }\end{array}$ \\
\hline $\begin{array}{l}\text { Безпілотні } \\
\text { літальні апарати } \\
\text { (БПЛА) }\end{array}$ & $\begin{array}{l}\text { Оперативний моніторинг посівів, транспортування (3 } \\
\text { метою внесення 33Р, транспортування ліків, } \\
\text { запчастин тощо) }\end{array}$ & $\begin{array}{l}\text { Усуває необхідність } \\
\text { виїздів агрономів у } \\
\text { поля, висока } \\
\text { продуктивність }\end{array}$ \\
\hline $\begin{array}{l}\text { Дистанційне } \\
\text { зондування } \\
\text { Землі (ДЗ3) }\end{array}$ & $\begin{array}{l}\text { Моніторинг полів на базі збору та обробки даних } \\
\text { супутникових знімків }\end{array}$ & $\begin{array}{l}\text { Моделювання врожаю, } \\
\text { оптимізація ресурсів }\end{array}$ \\
\hline \multicolumn{3}{|c|}{ Технологічні рішення } \\
\hline $\begin{array}{l}\text { Штучний } \\
\text { інтелект }\end{array}$ & $\begin{array}{l}\text { Вирішення конкретних задач технічними засобами за } \\
\text { рахунок їх здатності орієнтуватись у навколишньому } \\
\text { середовищі та враховувати дані моніторингу }\end{array}$ & $\begin{array}{l}\text { Лежить в основі } \\
\text { роботизації, ІоТ }\end{array}$ \\
\hline $\begin{array}{l}\text { Системи } \\
\text { машинного } \\
\text { навчання }\end{array}$ & $\begin{array}{l}\text { Забезпечує здатність технічного засобу самостійно } \\
\text { підвищувати ефективність виконання операцій } \\
\text { Навчання грунтується на обробці вхідних даних про } \\
\text { середовище та статистичної інформації щодо } \\
\text { ефективності роботи технічного засобу }\end{array}$ & $\begin{array}{l}\text { Лежить в основі } \\
\text { роботизації, ІоТ }\end{array}$ \\
\hline \multicolumn{3}{|c|}{ Інтегровані рішення } \\
\hline $\begin{array}{l}\text { Інтернет речей } \\
\text { (IoT) }\end{array}$ & $\begin{array}{l}\text { Об’єднує вищезгадані технології в єдину систему, } \\
\text { кастомізовану під потреби та особливості } \\
\text { господарювання кожного окремого } \\
\text { виробника/поля/ферми }\end{array}$ & $\begin{array}{l}\text { Компоненти: мережа } \\
\text { сенсорів, комп’ютерна } \\
\text { мережа, штучний } \\
\text { інтелект, машинне } \\
\text { навчання }\end{array}$ \\
\hline
\end{tabular}

Іншою сферою діжиталізації на мікрорівні $є$ сфера управління як окремими бізнес-процесами, так i господарською діяльністю сільськогосподарського виробника у цілому. У загальному можна виділити такі бізнес-процеси у рамках діяльності сільськогосподарських виробників: ресурсне забезпечення, виробництво сільськогосподарської продукції та продуктів іiі переробки, збут, здійснення несільськогосподарської діяльності. Наразі найбільш актуальною є цифровізація процесів управління ресурсами (передусім, управління земельними, фінансовими, трудовими, матеріально-технічними ресурсами).

Діджиталізація на мезорівні має дещо інші цілі порівняно із мікрорівнем. На мезорівні пріоритетними завданнями цифровізації аграрного сектора стає забезпечення досягнення цілей сталого розвитку регіону/громади. Для цього, всі активності щодо діджиталізації мають бути спрямовані переважно у бік стимулювання суб'єктів агробізнесу брати участь у досягнення глобальних цілей сталого розвитку. Таке стимулювання передбачає, передусім, створення умов, які б 
полегшали процес імплементації діджитал-технологій сільськогосподарськими виробниками, та, по-друге, зробили б деструктивну у контексті сталого розвитку діяльність економічно невигідною для підприємств.

3 одного боку, ринок діджитал-продуктів для агросфери стрімко зростає не лише у світі, але й в Україні і дефіциту у них наразі немає. Однак, з іншого боку, впровадження таких продуктів і технологій потребує залучення додаткових ресурсів, що значно уповільнює процес діджиталізації агросектору. До ресурсів, які мають першочергове значення у процесі цифровізації аграрного сектора, належать:

1) трудові ресурси. У даному випадку мова йдеться про, по-перше, наявність кадрів, які володіють необхідними для використання сучасних технологій кваліфікацією, вміннями та навичками i, по-друге, доступність до таких кадрів у сільській місцевості. Наразі вкрай важливо створити умови, які б уможливили виховання відповідних кадрів на місцях;

2) інформаційні ресурси, що включають банки даних про існуючі технології, сферу їх застосування, розробників, вартість впровадження тощо. Такі банки мають неперервно оновлюватись та враховувати зворотній зв'язок від всіх категорій користувачів;

3) фінансові ресурси, до яких, насамперед, мають належати інвестиційні та кредитні ресурси, а також власні кошти підприємств. Що ж стосується бюджетного фінансування, то, на нашу думку, наразі пріоритетним для місцевих органів влади має стати не пряме бюджетне фінансування сільськогосподарських підприємств, а створення умов, які б умовжливили самостійне залучення фінансових ресурсів виробниками. Бюджетні ж кошти слід спрямувати на розвиток інфраструктури ОТГ, що автоматично сприятиме покращенню інвестиційного іміджу громад та інвестиційної привабливості суб’єктів бізнесу.

Створення умов, які б забезпечили ширший доступ виробників сільськогосподарської продукції до перелічених ресурсів, може здійснюватися на базі геоінформаційних порталів, які акумулюватимуть, оброблятимуть та надаватимуть доступ до даних про ОТГ всім потенційним користувачам. Розробка та популяризація геоінформаційних порталів громад може забезпечити значні вигоди як для окремих суб'єктів агробізнесу, так і для громади в цілому. Основною метою створення геоінформаційних порталів $\epsilon$ акумуляція накопичення та обробка геопросторових та інших даних відповідно до можливих запитів якомога ширшого кола користувачів i представлення даних у максимально сприятливому для їх сприйняття вигляді. В основі процесів формування та використання геоінформаційних порталів мають лежати такі принципи:

1) масиви даних мають відповідати реальним потребам потенційних користувачів. Для цього створюються складні багаторівневі бази даних, які містять як позиційні дані (геопросторові характеристики об’єктів у вигляді їх координат), так i атрибутивні (семантичні дані, що не мають географічних координат та описують кількісні або якісні характеристики об'єктів). У процесі обробки інформації спеціаліст має здійснювати геокодування атрибутивних даних шляхом 
присвоєння їм просторових координат;

2) неперервне оновлення даних, що забезпечить можливість виявлення та відслідковування трендів, побудову прогнозів, ідентифікацію та оцінку ризиків, фактичних і можливих флуктуацій;

3) визначення повного переліку потенційних інформаційних запитів;

4) підготовка внутрішніх спеціалістів ОТГ, які матимуть достатню кваліфікацію для адміністрування, наповнення та оновлення порталів відповідно до нових запитів потенційних користувачів;

5) пріоритетність одного багаторівневого порталу для сукупності користувачів, а не кількох геопорталів для окремих груп користувачів. Для багаторівневого порталу ключове значення має визначення ролей користувачів та диференціація доступу різних груп користувачів відповідно їх функцій та потрібної їм інформації. Дані такого порталу пропонується класифікувати за двома головними критеріями, а саме: тип стейкхолдерів та напрям прийняття рішень на основі даних порталу;

6) обгрунтування методології збору інформації для оновлення баз даних. В даному випадку ключовим є визначення не лише джерел, але й методів наповнення баз даних. Основними джерелами наповнення баз даних ОТГ можуть бути супутникові знімки та знімки безпілотних літальних апаратів; офіційні дані статистики; дані державних та місцевих органів влади; дані про конкретні об'єкти (суб'єкти бізнесу, особисті селянські господарства, об'єкти інфраструктури тощо), які збираються централізовано на рівні ОТГ; дані соціометричних опитувань (зазвичай збираються за допомогою спеціальних сервісів, інтегрованих у геоінформаційні системи).

Функціональна модель процесу створення та адміністрування геоінформаційного порталу ОТГ складатиметься з трьох основних функціональних блоків. Першим блоком $\epsilon$ розробка порталу та підготовка спеціалістів, які у подальшому його адмініструватимуть та оновлюватимуть (рис. 1). На наш погляд, оптимальним $\epsilon$ створення порталу зовнішніми спеціалістами за участю представників ОТГ. Обов'язково у цей блок слід включити юридичні процедури взаємодії ОТГ із розробниками порталу. Навчання представників від ОТГ для їх подальшої роботи з геоінформаційними системами пропонується здійснювати на базі закладів вищої освіти (ЗВО), у межах яких доцільно створити спеціалізовані структурні підрозділи. Вони надаватимуть послуги з розробки порталів, навчання спеціалістів ОТГ, формування компетентностей у студентів щодо роботи 3 геоінформаційними системами. 


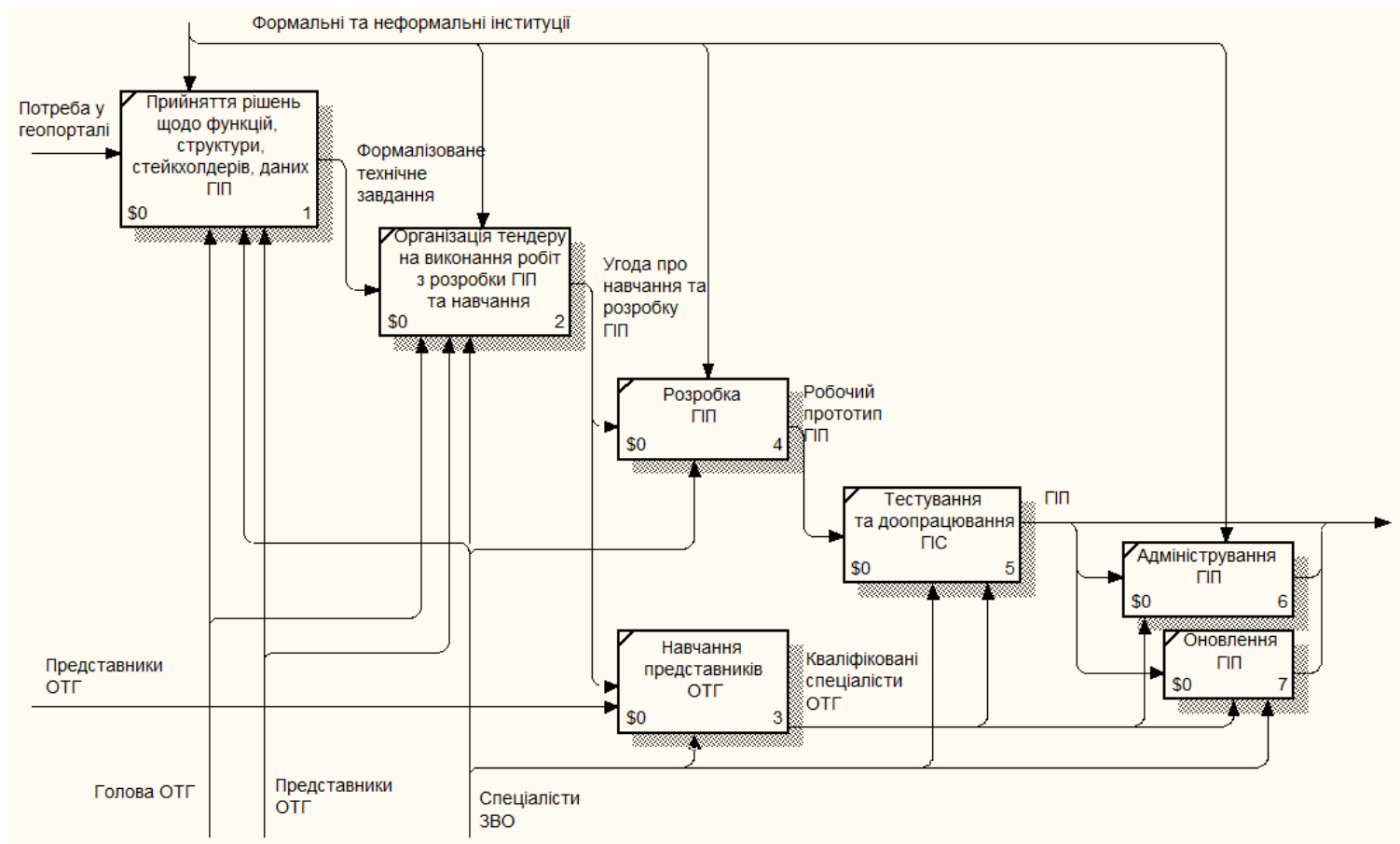

\section{Рис. 1. Функціональна IDEF0-модель розробки та адміністрування геінформаційного порталу ОТГ}

Примітка: ГІП - геоінформаційний портал ОТГ.

Джерело: власні дослідження.

Другий функціональний блок моделі включає оновлення даних, перегляд структури бази даних, виявлення та виправлення помилок у роботі тощо. Чисельність спеціалістів, що виконуватимуть відповідні функції, варіюватиме залежно від розміру бази даних, періодичності збору інформації, методів акумулювання та обробки даних. Окремим блоком процесу оновлення геопорталів ОТГ $\epsilon$ періодичне обговорення структури, системи даних, користувачів геоінформаційного порталу, у який слід залучати представників всіх стейкхолдерів.

Третім рівнем діджиталізації аграрного сектора України є макрорівень, у межах якого слід забезпечити максимально ефективну організацію інформаційного забезпечення процесу формування та імплементації аграрної політики країни. Це сприятиме досягненню як глобальних цілей сталого розвитку, так i однієї iз ключових економічних цілей держави - створення та утримання стійких конкурентних переваг на світових аграрних ринках. Першоосновою ефективної аграрної політики є високий рівень іiі обгрунтованості, який залежить від, того, чи буде досягнуто бажані значення цільових показників аграрної політики. Перед тим, як імплементувати нові заходи, необхідно змоделювати ймовірні наслідки їх впровадження та порівняти потенційні ефекти із цілями.

Процес підтримки прийняття рішень у сфері агарної політики має базуватись на математично обгрунтованих економічних оцінках та прогнозах розвитку аграрного сектору країни. Важливо враховувати два аспекти майбутніх результатів аграрної політики, а саме: 1) прогнозні значення цільових показників аграрної політики; 
2) прогнозні значення основних показників розвитку всіх галузей сільського господарства. Останній пункт $є$ особливо важливим, оскільки часто покращення одних показників призводить до погіршення інших. У контексті прогнозування розвитку аграрного сектора України у світовому геоекономічному просторі, актуальним $є$ побудова сценарних прогнозів розвитку тих галузей, які є ключовими у формуванні конкурентних переваг країни на світових аграрних ринках. Зокрема, це види аграрної продукції, які Україна експортує. Узагальнену схему методики прогнозування відображено на рис. 2.

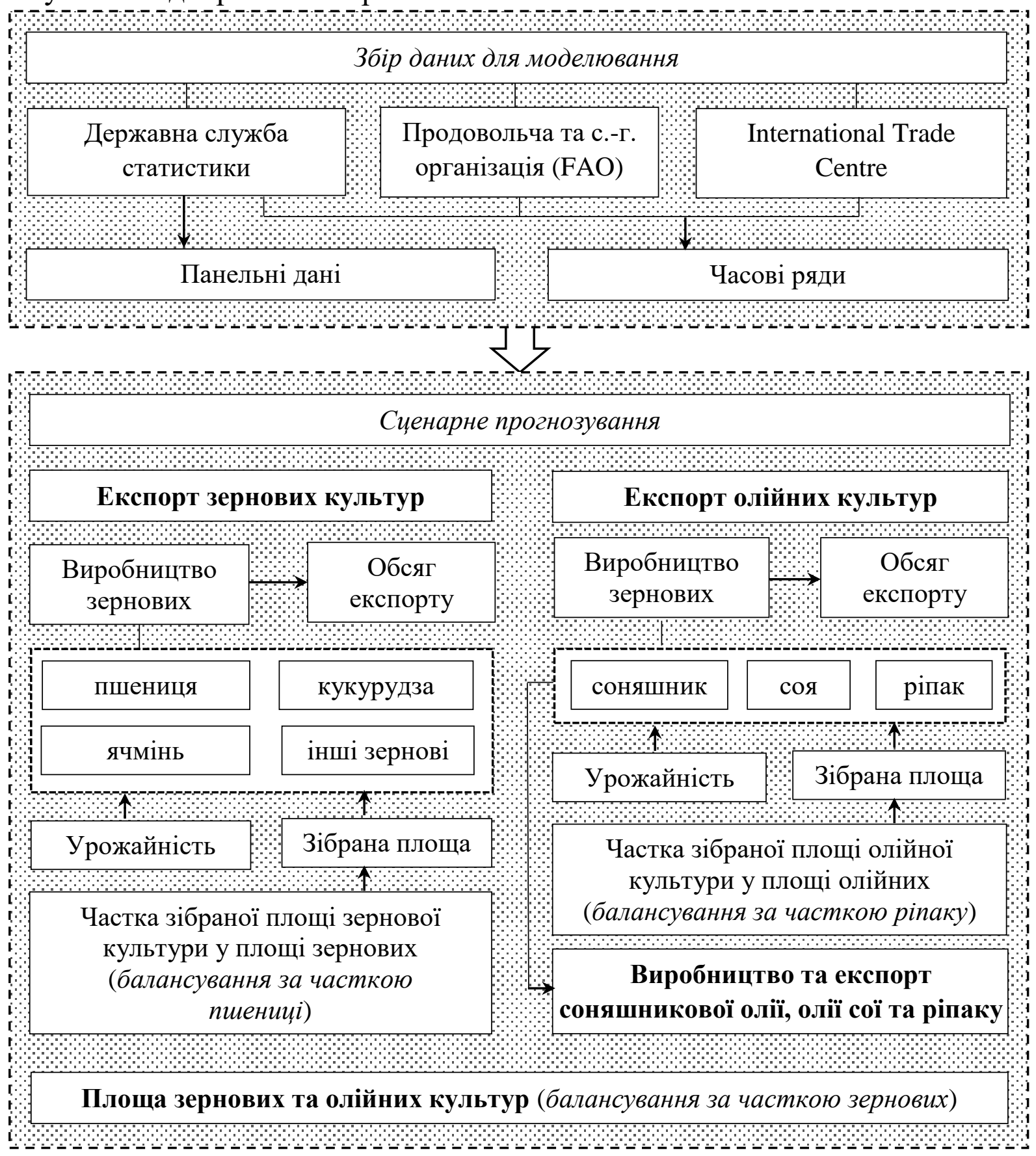

Рис. 2. Алгоритм сценарного прогнозування експорту основних видів аграрної продукції 
Використання запропонованої методики дає змогу розробляти середньострокові прогнози розвитку сільського господарства України та експорту сільськогосподарської продукції. Узагальнюючи результати прогнозування ринків продукції рослинництва встановлено, що урожайність олійних культур зростатиме у наступні 10 років. Урожайність соняшника та ріпаку можуть стати приблизно однаковими, тоді як продуктивність посівів сої може бути відносно нижчою, незважаючи на тенденцію до збільшення. Суттєве зростання урожайності соняшника пояснюється використанням високопродуктивних сортів культури та гібридів.

Прогнозоване зменшення загальної площі зернових культур у наступні 10 років зумовлене зростанням зібраної площі олійних, вирощування яких відповідно до розроблених прогнозів буде вигіднішим, порівняно із зерновими. Мультиплікативний ефект від зростання зібраної площі та рівня урожайності зумовить зростання валового збору всіх олійних культур. Якщо припустити, що внутрішня потреба у відповідній сільськогосподарській продукції залишатиметься сталою та повною мірою задовольнятиметься вітчизняними товаровиробниками, то обсяги експорту пшениці, кукурудзи, соєвих бобів і ріпаку повторюватимуть динаміку їх валового збору (рис. 3).

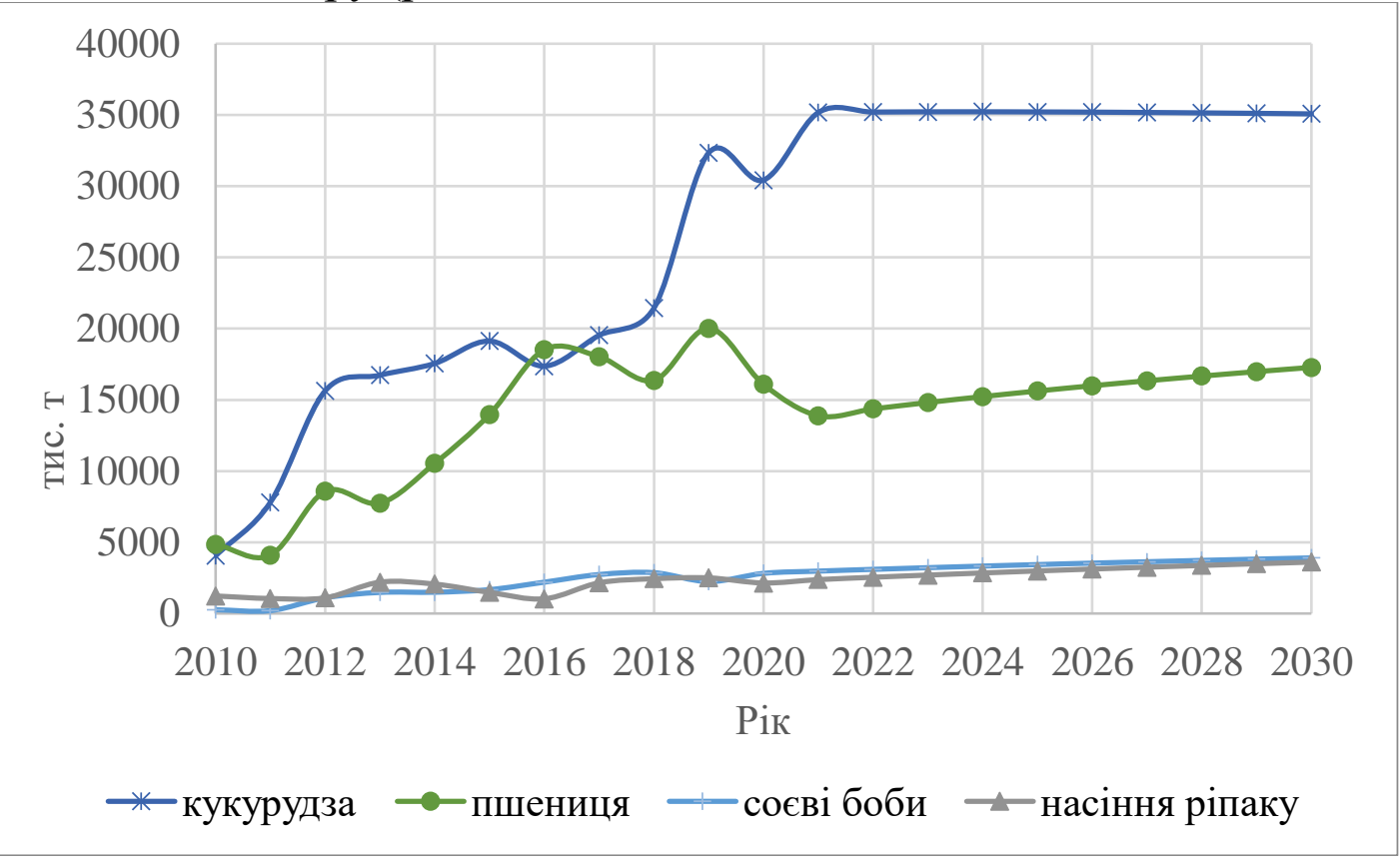

\section{Рис. 3.8. Прогнозування обсягів експорту основних видів продукції рослинництва}

Примітка: у 2020 р. використано розрахункові дані.

Подальша обробка отриманих прогнозних оцінок полягає має передбачати визначення потенційних змін порівняно із базовими прогнозами, які можуть мати місце у разі змін державної аграрної політики. Саме на базі отриманих моделей доцільно прогнозувати ефекти, що матимуть місце як результат тих чи інших інституціональних трансформацій. 


\section{Лimepamypa:}

1. Гудзь О. Є. Цифрова економіка: зміна цінностей та орієнтирів управління підприємствами. Економіка. Менеджмент. Бізнес. 2018. o 2(24), С. 4-12.

2. Гуренко А.В., Гашутіна О.Е. Напрями розвитку систем управління в умовах діджиталізації бізнесу в Україні. Економіка і суспільство. 2018. № 19, С. 23-27.

3. Жосан Г. Стан розвитку діджиталізації в Україні. Economic Analysis. Vol. 30. No. 1. Part 2. 2020, Р. 44-52.

4. Руденко М.В. Проблеми та перспективи використання Інтернет-технологій у сільськогосподарських підприємствах. Економіка АПК. 2019. № 10.

5. Руденко М. В. Технології цифрової трансформації сільськогосподарських підприємств. АГРОСВIT. 2019. № 23, С. 8-18.

6. Deichmann U., Goyal A., Mishra D. Will Digital Technologies Transform Agriculture in Developing Countries? Agricultural Economics. 2016. Vol. 46. Iss. S1, P. 21-33.

7. Fountas S., Espejo-Garcia B., Kasimati A., Mylonas N., Darra N. The Future of Digital Agriculture: Technologies and Opportunities. IT Professional. № 22(1), P. 24-28.

8. Sulimin V. V., Shvedov V. V., Lvova M. I. Digitization of agriculture: innovative technologies and development models. IOP Conference Series: Earth and Environmental Science. 2019. URL: DOI:10.1088/1755-1315/341/1/012215. (дата звернення: 26.06.2021)

9. Trendov Nikola M., Varas S., Zeng M. Digital Technologies in Agriculture and Rural Areas : briefing paper. Rome : Food and Agriculture Organization of the United Nations, 2019. 18 p.

\section{References:}

1. Hudz, O. E. (2018). Tsyfrova ekonomika: zmina tsinnostei ta oriientyriv upravlinnia pidpryiemstvamy [Digital economy: changing values and guidelines of enterprise management]. Ekonomika. Menedzhment. Biznes - Economy. Management. Business, No 2(24), 4-12 [in Ukrainian].

2. Hurenko, A. V., Hashutina, O. E. (2018). Napriamy rozvytku system upravlinnia v umovakh didzhytalizatsii biznesu v Ukraini [Directions of management systems development in the conditions of business digitalization in Ukraine]. Ekonomika i suspilstvo - Economy and society, №19, 23-27 [in Ukrainian].

3. Zhosan, G. (2020). Stan rozvytku didzhytalizatsii v Ukraini [The state of development of digitalization in Ukraine]. Economic Analysis, Vol. 30. No. 1. Part 2, 44-52 [in Ukrainian].

4. Rudenko, M. V. (2019). Problemy ta perspektyvy vykorystannia Internet-tekhnolohii u silskohospodarskykh pidpryiemstvakh [Problems and prospects of using Internet technologies in agricultural enterprises]. Ekonomika APK - Economics of agro-industrial complex, №10 [in Ukrainian].

5. Rudenko, M. V. (2019). Tekhnolohii tsyfrovoi transformatsii silskohospodarskykh pidpryiemstv [Technologies of digital transformation of agricultural enterprises AHROSVIT, №23, 8-18 [in Ukrainian].

6. Deichmann U., Goyal A., Mishra D. Will Digital Technologies Transform Agriculture in Developing Countries? Agricultural Economics. 2016. Vol. 46. Iss. S1, P. 21-33.

7. Fountas S., Espejo-Garcia B., Kasimati A., Mylonas N., Darra N. The Future of Digital Agriculture: Technologies and Opportunities. IT Professional. № 22(1), P. 24-28.

8. Sulimin V. V., Shvedov V. V., Lvova M. I. Digitization of agriculture: innovative technologies and development models. IOP Conference Series: Earth and Environmental Science. 2019. URL: DOI:10.1088/1755-1315/341/1/012215. (дата звернення: 26.06.2021)

9. Trendov Nikola M., Varas S., Zeng M. Digital Technologies in Agriculture and Rural Areas : briefing paper. Rome : Food and Agriculture Organization of the United Nations, 2019. 18 p. 